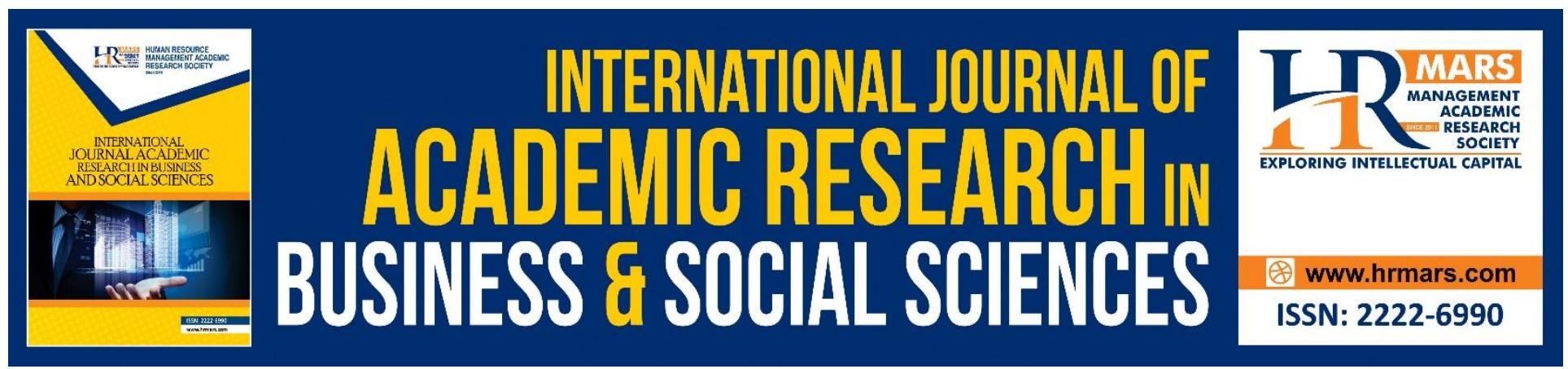

\title{
Booming of Online Shopping in Malaysia: Do Customers Satisfy with Parcel Delivery Service?
}

Fadilah Siali, Apple Wong Su Wen \& Mohd Uzairi Ahmad Hajazi

To Link this Article: http://dx.doi.org/10.6007/IJARBSS/v8-i12/5042

DOI: $10.6007 /$ IJARBSS/v8-i12/5042

Received: 04 Nov 2018, Revised: 19 Dec 2018, Accepted: 24 Dec 2018

Published Online: 26 Dec 2018

In-Text Citation: (Siali, Wen, \& Hajazi, 2018)

To Cite this Article: Siali, F., Wen, A. W. S., \& Hajazi, M. U. A. (2018). Booming of Online Shopping in Malaysia: Do Customers Satisfy with Parcel Delivery Service? International Journal of Academic Research in Business and Social Sciences, 8(12), 415-436.

Copyright: (C) 2018 The Author(s)

Published by Human Resource Management Academic Research Society (www.hrmars.com)

This article is published under the Creative Commons Attribution (CC BY 4.0) license. Anyone may reproduce, distribute, translate and create derivative works of this article (for both commercial and non-commercial purposes), subject to full attribution to the original publication and authors. The full terms of this license may be seen

at: http://creativecommons.org/licences/by/4.0/legalcode

Vol. 8, No. 12, 2018, Pg. 415 - 436

http://hrmars.com/index.php/pages/detail/IJARBSS

JOURNAL HOMEPAGE

Full Terms \& Conditions of access and use can be found at http://hrmars.com/index.php/pages/detail/publication-ethics 


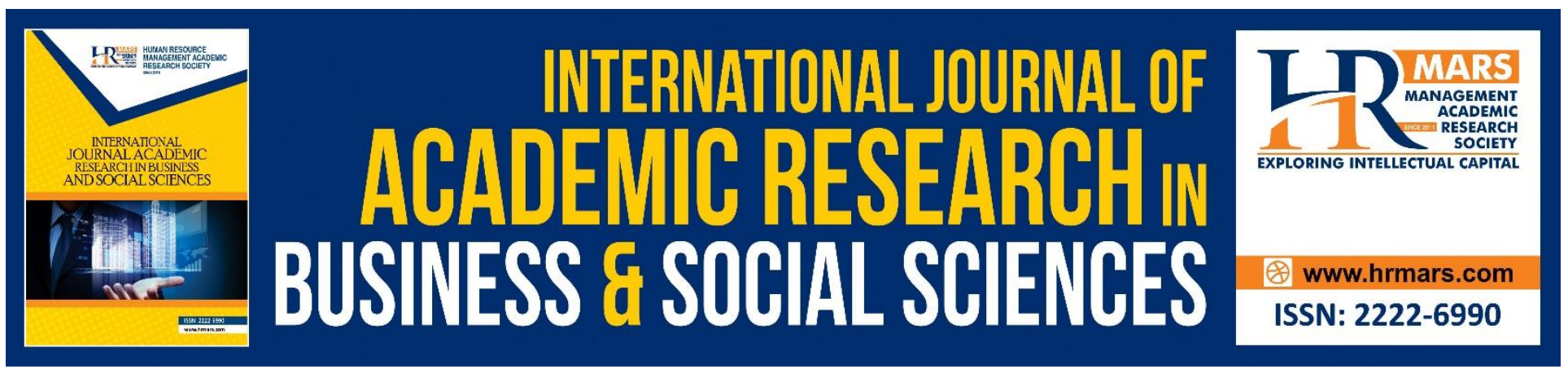

\title{
Booming of Online Shopping in Malaysia: Do Customers Satisfy with Parcel Delivery Service?
}

\author{
Fadilah Siali, Apple Wong Su Wen \& Mohd Uzairi Ahmad Hajazi \\ Faculty of Economics and Business, Universiti Malaysia Sarawak \\ Email: sfadilah@unimas.my
}

\begin{abstract}
Fuelled by rapid growth of online shopping, third-party service provider such as courier service company has become an increasingly important and crucial element in facilitating seamless movement of goods within the supply chain network. Nevertheless, courier service companies also faced operational challenges as they need to cope with the ever increasing demand from the ecommerce industry, with their customer satisfaction is at the stake. The objective of this research, therefore, is to measure the customer satisfaction towards parcel delivery service by a leading courier service company in Malaysia. In this research, customer satisfaction is observed through five independent variables, namely reliability, responsiveness, assurance, empathy and price. 400 set of questionnaires was distributed to the targeted respondents, and the data collected was analysed using Pearson correlation and multiple regression analysis. The result showed that reliability, responsiveness, assurance, empathy and price positively affect customer satisfaction towards parcel delivery service of courier company. The impact of each variable towards customer satisfaction level is also discussed.
\end{abstract}

Keywords: Customer Satisfaction, Online Shopping, Courier Service, Logistics

\section{INTRODUCTION}

Malaysia has huge potential for the growing of e-commerce market, as the country saw an improved internet access, high mobile penetration and enhanced security (Kim, 2015). At 67\%, Malaysia is the third highest country in Southeast Asia in term of internet users. The country has seen its e-commerce market grew at $31 \%$ between 2010 to 2014 and the market size is expected to grow to reach 3.1 billion US Dollar by 2018 (Kim, 2015). This ever accelerating growth of e-commerce market has developed enormous opportunities for businesses within the supply chain such as courier service companies whose service includes parcel delivery service.

According to Choy, Ma and Koo (2013), in the context of logistics, parcel delivery service is considered as a part of third party service provider, and it is needed to facilitate a smooth movement of goods 
within the supply chain network. In Malaysia, there a numbers of logistics companies that offer parcel delivery service, with the largest being National Courier Services. Established in 1988, the company has the largest courier fleet in the country and the widest network coverage. Its parcel delivery service covers rural and urban areas in Malaysia, offering same-day delivery, next-day delivery and time certain service. In addition, it also provides international express deliveries to over 200 countries worldwide. Due to the outstanding growth of online shopping and business, the demand for National Courier Services has increased significantly, and as a result, the company has recorded an $21.6 \%$ increase of revenue for the financial year 2014.

As mentioned earlier, the development of online shopping has caused high demand for dedicated delivery services to the end users (Morganti, Seidel, Blanquart, Dablanc, \& Lenz, 2014). Online buyers have high expectations for their parcel delivery service (Xu, Ling, \& Li, 2013). Therefore, as a parcel delivery service provider, it is essential for the courier company to make sure that all parcels are delivered to achieve customer satisfaction (Mensah, 2014). Looking at customer satisfaction, this research aims to measure the customer satisfaction based on several variables, namely reliability, responsiveness, assurance, empathy and price.

Back to the National Courier Services, whose tagline is "Guaranteed Next Day Delivery", the increasing number of parcels has made them not being able to perform according to their promise, i.e. for most of the time, parcel was not delivered in time. This would cause customer dissatisfaction towards National Courier Services, and customers might switch to another courier service company if they do not receive their parcel on time. Reliability is acknowledged as the capability of a company to accomplish the service they have promise in an accurate way. In the context of courier service, it means the timeliness of the parcel delivery by the company to reach customers. Therefore, does reliability of parcel delivery affect the customer satisfaction towards National Courier Services?

Meanwhile, another case related to National Courier Services was relating to the company's responsiveness towards customer. Mokhtar (2013) stated one of the National Courier Services customers posted a parcel to overseas but the parcel had damage and its contents lost during the delivery period. The parcel should be arrived one week after the delivery. The customers had made complaint but National Courier Services refuses to pay for the damage and loss. As courier company, National Courier Services Company should able to give prompt service to their customers, and they need to be responsible to the parcel delivery. With this incident as a case in point, does the responsiveness of National Courier Services Company affect the customer satisfaction?

In another occasion, as reported in an online portal called ComplaintBoard.com, which is a platform for consumers to post complaints, National Courier Services received a lot of complaint about frequently late in updating their parcel delivery tracking records, making customers unable to trace the location of their parcel. As a courier service company, updating tracking records is important as this will give assurance to customer about their parcel delivery. Should the company unable to deliver parcel on time, customers must be notified the soonest possible. The company need to convey the 
confidence and trust of their customers through assurance of their service. Thus, does assurances of National Courier Services influences the customer satisfaction?

In addition, another customer complaint was made via a mainstream daily newspaper, in which the complainant, whose wife had walking difficulty, was unable to collect parcel at the company's parcel collection center on behalf of his wife, even though he produced authorization letter to collect the parcel. Although the complainant understood that since the parcel was credit card and the credit card owner should present himself/herself for collection, he argued that on the day of delivery, both himself and herself was at home in their apartment unit, waiting for the delivery. However, they did not receive any call from the postman, nor the security guard about the delivery. The notification of the attempted delivery also did not state the time. Such incident shows that empathy affect customer satisfaction.

Another element that may affect customer satisfaction is price. Since the implementation of Good and Service Tax (GST) by Malaysian Government in 1 April 2015, all goods and services including postage and delivery service is taxable at six percent. Although the tax is paid to the government, it is collected by the merchant, in this case, the National Courier Services. Therefore, will any price increment, regardless whether due to government tax, or cost of product/services, affect customer satisfaction?

Due to the booming of online shopping, not only courier companies have to cope with the increasing number of demand i.e. parcel, but they also have to face the higher expectation from customers, as the latter expect excellent parcel delivery service. Without them, it may affect the customer satisfaction towards parcel delivery service. In order to measure customer satisfaction, this research has taken an approach by using several variables taken from service quality model (SERVQUAL), which has been developed by Parasuraman, Zeithml, and Berry (1985), with an additional variable of price. The context of this research is set towards customer satisfaction on the parcel delivery of National Courier Service since the booming online shopping in Malaysia.

\section{LITERATURE REVIEW}

\section{Customer Satisfaction}

Customer satisfaction can be defined as a component of products or services provided by an organization to reach customers' expectation (Roslan, Wahab, \& Abdullah, 2015; Munusamy, Cselliah, \& Hor, 2010). It is also can be defined as a result which a goods or service conveys a satisfying level of consumption-related satisfaction (Su, Swanson \& Chen, 2016; Oliver, 1997). Besides, it is also known as inner feelings of the customers on comparing their expectation with the achievements of the purchase and customers past purchase experience (Hosseini, Mosayebi, \& Khorram, 2013; Wirtz, Mattila, \& Tan, 2000). Customers would show their expression such as happy, angry or upset after elaborate the performance of a products and services.

Customer satisfaction is important as it reflects the personal customer evaluations of the quality performance related with the consumption experience. It is acknowledged as a result of service 
quality related to the quality of the products or services delivered in a positive way to the customers. When the level of perceived quality of the good or service increased, it enhanced the level of customer satisfaction. When customers were satisfied with the products, they would repurchase it again. Therefore, companies have to make sure that their products able to satisfy the customers (Wulan \& Husaeni, 2015). In addition, companies should study about customer satisfaction in order to understand the company's performance from the customers' perception. Bradic, Kosar, and Kalenjuk (2013) mentioned that customer satisfaction is important to the survival of a company.

\section{SERVQUAL Theory}

According to Su, Swanson, and Chen (2016), Parasuraman, Zeithml, and Berry (1988) has developed SERVQUAL, a scale of service quality measurement for studying customer satisfaction. The original SERVQUAL theory consists of ten dimensions which were reliability, tangibles, competence, responsiveness, security, courtesy, communication, understanding, access and credibility (Yousapronpaiboon, 2014). After further analysis, the dimension was reduced to five - tangibility, assurance, reliability, empathy and responsiveness (Stefano, Casarotto, Barichello, \& Sohn, 2015; Parasuraman, Zeithaml \& Berry, 1985).

In measuring service quality, SERVQUAL perceives quality in terms of how well a service delivery meets their expectation. The model identifies five gaps that can affect the perception of quality as shown in Figure 1. According to Siami and Gorji (2012), and Large and Konig (2009), Gap 1 is the relationship between management's perceptions of the customers' expectation and expected service by customers, while Gap 2 is the relationship between management's perceptions of the customers' expectation and service quality specifications. Meanwhile, Gap 3 is identified by the relationship between service quality specifications and service delivery including pre and post contacts. Then, Gap 4 explains the difference between service delivery intentions and external communications to the consumers, and finally Gap 5 is the relationship between perceive service and expected service by customers. Yousapronpaiboon (2014) stated the service quality (SERVQUAL) score was calculated by using perceived $(P)$ service and expected (E) service with respects to the five dimensions - reliability, tangibles, assurance, responsiveness and empathy. Calculation of each item of gap was SERVQUAL score $=\mathrm{P}-\mathrm{E}$. 
INTERNATIONAL JOURNAL OF ACADEMIC RESEARCH IN BUSINESS AND SOCIAL SCIENCES Vol. 8, No. 12, Dec, 2018, E-ISSN: 2222-6990 @ 2018 HRMARS

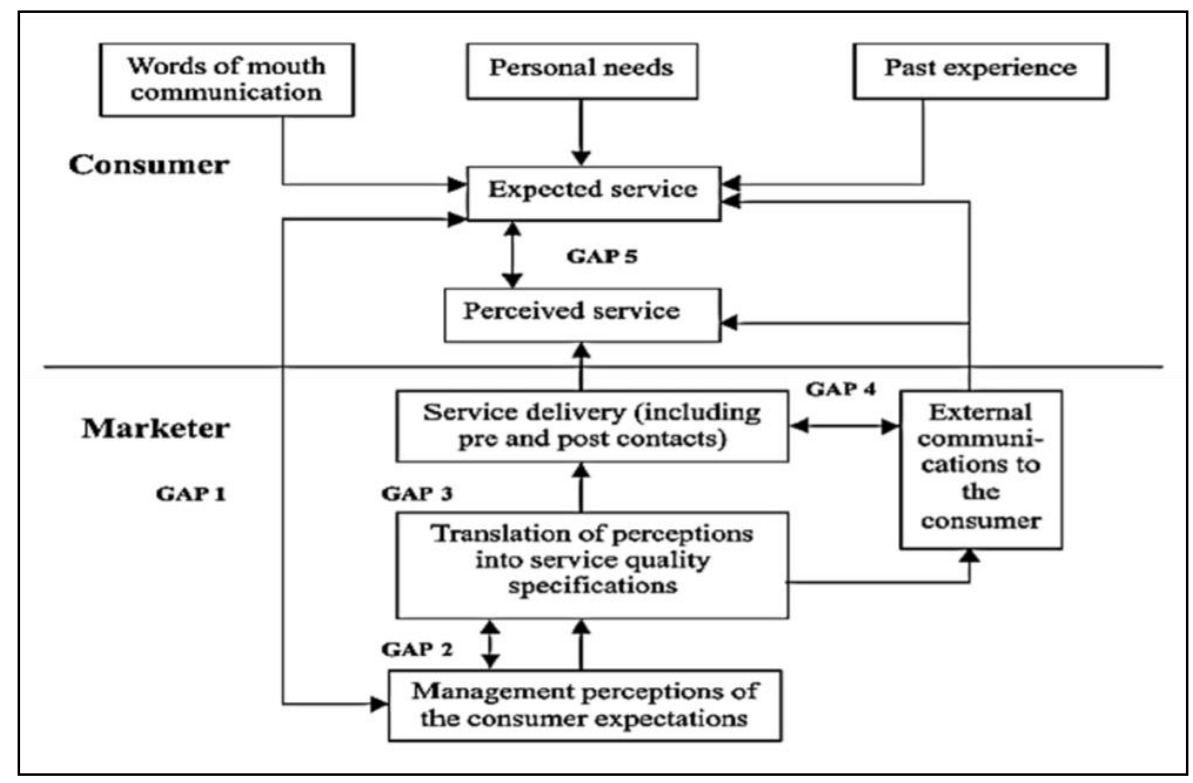

Figure 1: Theoretical framework for the Service Quality (SERVQUAL) model Source: Felix (2017), Parasuraman, Zeithaml, and Berry (1985; 1988).

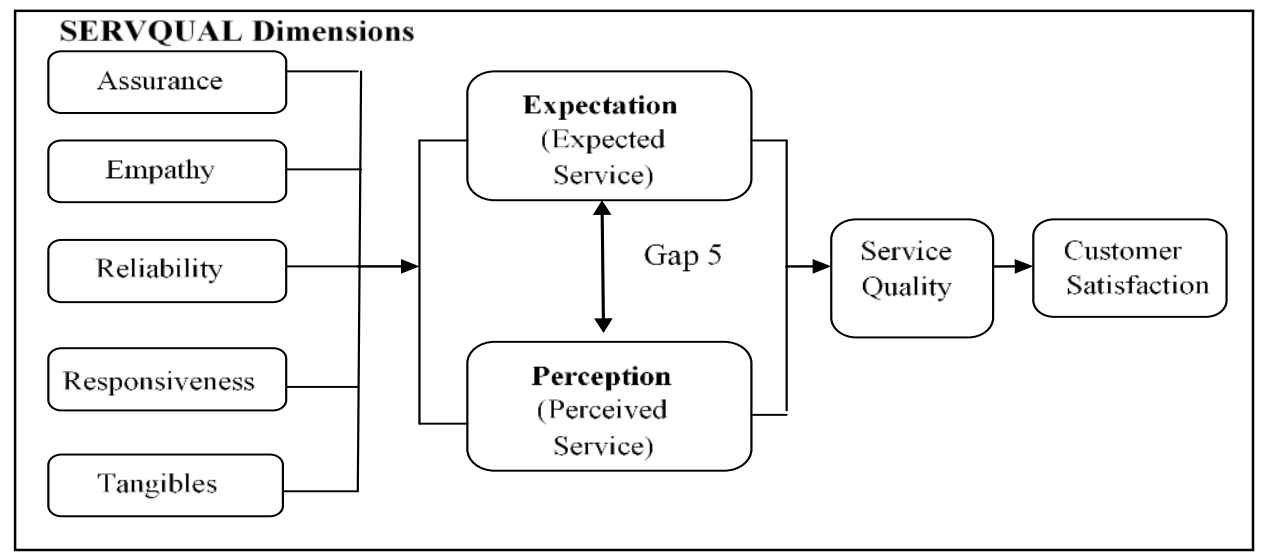

Figure 2: Conceptual Framework of Gap 5

Source: Goh, Kow, Lee, Loh, and Sam (2013); Abili, Thani, Mokhtarian, and Rashidi (2011)

Figure 2 shows the zoom in of Gap 5 conceptual framework and it was the main focus in this study. Gap 5 was the overall gap in customers' perception and expectation on service quality, and it is the most important gap because it compares the actual and perceived service delivery. The first four gaps influence the overall gap between customer's perception and customer expectation towards service quality, Gap 5 (Datta \& Vardhan, 2017; Parasuraman, Zeithaml, \& Berry, 1988), therefore it could be said that Gap 1 to Gap 4 was the major contributors to the Gap 5 which Gap $5=\mathrm{f}($ Gap 1, 2, 3, 4). When the expectation of customers was higher than its experience, the gap between customers' experience and expectation could be negative. If it shows a negative gap score, the expectations have 
INTERNATIONAL JOURNAL OF ACADEMIC RESEARCH IN BUSINESS AND SOCIAL SCIENCES Vol. 8, No. 12, Dec, 2018, E-ISSN: 2222-6990 C 2018 HRMARS

not been exceeded, therefore service quality was not perceived to be satisfied. Therefore, it is necessary to manage the gaps between perceptions and expectations among employers, customers and company management to manage service quality (Arokiasamy and Abdullah, 2013).

\section{Research Framework}

The research framework was inspired by the Gap 5 in SERVQUAL. Based on the Figure 3, research framework in this study used only four of the SERVQUAL dimensions which are reliability, responsiveness, assurance and empathy towards the customer satisfaction in parcel delivery of National Courier Services. In addition to the four, a new variable price was added.

According to Razak, Nirwanto, and Triatmanto (2016), reasonable price would rise the customer satisfaction towards a product or service. This was because affordable price can increase customer satisfaction and make the customer interest to repurchase the product and service. One of the variables, tangible was not implemented in this study because there was little presence of physical dimension can be observed from parcel delivery services. Five variables which was responsiveness, reliability, empathy, assurance and price was the independent variables. The dependent variable in this study was customer satisfaction.

Independent Variable

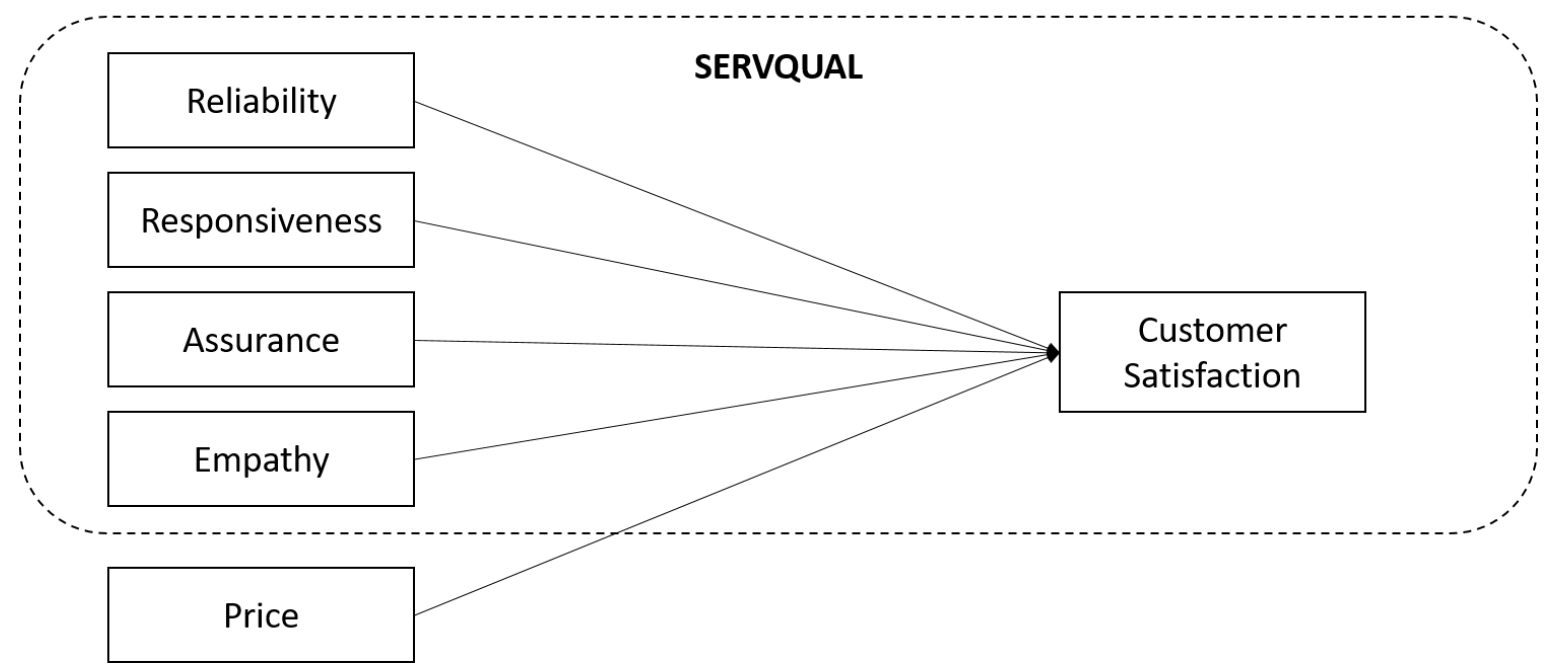

Figure 3: Conceptual Framework.

Source: Adapted from Parasuraman, Zeithaml, Berry (1985)

\section{Reliability}

Reliability is known as the ways firm execute services in a right condition without make any mistake. It is the measure of stability of a company performance and how can a company be dependable (Choy, Ma \& Koo, 2013). In the research of Omar, Saadan and Seman (2015), reliability is found to be one of the important dimensions in the service quality. Company has to perform as what they had 
promises in order to gain trust from their customers. There are several aspects in reliability dimension that would make customers be aware of consistency and credibility such as the accuracy of online booking record, complete order service, accurate delivery service, and availability of website, trusted promotion promise and company being honest about its product offers. In the context of parcel delivery service, reliability can be measured as the time taken to deliver a parcel in a package delivery context, and how many times the parcel reached the right place and final destination.

According to Hennayake (2017), reliability is known as the ability of a company or organization to perform their service accurate and reliably as promised. In other word, reliability can be defined as the company ability to delivers on its promise such as promises about delivery service, problem resolution, pricing and service provision. Since customers tend to trust and do businesses with the companies which able to retain their promise.

Reliability has significant influence towards customers and it was an analyst of customer satisfaction (Mahfooz, 2014; George \& Kumar, 2014; Das et al., 2010; Jamal \& Anastasiadou, 2009). For instance, if a company were able to keep their promises, the customer satisfaction would increase (Mahfooz, 2014; Yuen \& Chan, 2010). The research on the customers of several bank in the Saudi capital city of Riyadh in the year 2014 indicated reliability has a negative relationship towards customer satisfaction but no significant effect (Aljasser \& Sasidhar, 2016; Ghalib, 2014). As conclusions for the result of previous studies, the reliability was an important influential factor on the customer satisfaction. Therefore, the hypothesis was formed based on the discussion above as follow:

H1: Reliability of National Courier Services parcel delivery positively affects customer satisfaction.

\section{Responsiveness}

Gulc (2017) stated responsiveness dimensions is based on the fast response and ability to give feedback if the customers have problem to the company. It identifies the willingness of employees to solve a problem and their responsiveness towards the customer needs was the important factors in service quality (Goh, Kow, Lee, Loh, \& Sam, 2013; Johnston, 1995). Omar, Arrifin and Ahmad (2016), in their research also described responsiveness as the willingness of company service providers to provide quick service and prepared to help their customer in solving problems, feedback, requests and questions. In the context of parcel delivery service, this could mean that the response given by a parcel delivery service provider to their customers.

Employees need to be responsible to service the customers and provide a fast service to their customers. Customers would show negative perceptions of quality if employees keep the customers waiting for no acceptable reason (Millas, 2013; Liu, 2005). The ability to professionally do fast recover on the negative perception can create a positive perceptions of quality. Responsiveness has the main impact on perception of e-service quality affect the total of customer satisfaction perception (Firdous, 2017). As summarizes the result of previous study, the responsiveness dimensions were an important influential factor toward the customer satisfaction. Therefore, the hypothesis was formed based on the discussion above as follow: 
INTERNATIONAL JOURNAL OF ACADEMIC RESEARCH IN BUSINESS AND SOCIAL SCIENCES

Vol. 8, No. 12, Dec, 2018, E-ISSN: 2222-6990 @ 2018 HRMARS

H2: Responsiveness of National Courier Services parcel delivery positively affects customer satisfaction.

\section{Assurance}

According to Ma (2012); Madu and Madu (2002), assurances shows the ability to deliver confidence and trust to their users. The company must guarantee their employees were well training and knowledgeable about their task. Employees must be polite in their response to the customer's complaint, questions and feedback. Employees that can gain the confidence and trust of the customers as a trained worker is one of the question a company should think through. This was because when customers were not happy and comfort with the service provided by employees, they tend to switch to others company and would not return to do business with the previous company.

In research of Goh, Kow, Lee, Loh and Sam (2013) indicated a skilled employees or worker would make sure their customers be provided a good, kind and fast response to their problem. This was one of the alternative to deliver trust and assurance to customers. Employees can show their ability to convey trust and confidence with their high understanding and politeness. The good service provided builds a positive relationship between the service provider and customers (Baruah, Nath, \& Bora, 2015; Parasuraman, Zeithaml \& Berry, 1988).

According to Phiri and Mcwabe (2013); Cook (2000), the most important aspects of service quality was assurance. This can be proved by the facts where customers choose to deal with people or company they can trust. The dimension such as assurance is needed to guarantee the customer satisfaction. The relationship between assurance and customer satisfaction had been verified by several studies such as Shubasini (2016), Phan (2015) and Shanka (2012). As conclusion for the result of previous studies, the assurances was an important influential factor towards customer satisfaction. Therefore, the hypothesis was formed based on the discussion above as follow:

H3: Assurance of National Courier Services parcel delivery positively affects customer satisfaction.

\section{Empathy}

In the research of Khamis (2013), empathy is known as the delivered of caring and individualized attention to the customers. It includes communication between employees and customers, understanding the customer needs and access customers. This research was supported by Felix (2017), where it stated empathy showed the kind and individually attention a company provides to their customers. Empathy also consists of physical and socials of their ease of contact, communicate with customers in appropriate language and listen to their feedback and lastly had an effort to know customer's preference and needs.

In addition, empathy is also can be defined as the understanding of a company towards the needs and wants of customers and give individual attention to their customers (Qadri, 2015). Meanwhile, Nautiyal (2014) indicated empathy shows that employees were approachable, helpful and aware to the needs of customers. Employees should be fully involved with the customers in every relation. The ways a company cares and deliver individual attention to their customer makes their customers feel 
specials and valued related to the empathy of service quality. Thus, when the customers feel the individualized attention provided, there was a big chance the customers would retain and doing business with the company

As a result, it can be said that empathy is one of the important elements that influence customer satisfaction and their loyalty. When employees provide excellent service to their customer, it would increase their customer satisfaction level and customer tend to stay loyal (Goh, Kaw, Lee, Loh \& Sam, 2013; Yavas, Bilgin, \& Shemwell, 1997; Ladhari, Ladhari, \& Morales, 2011). To conclude the result of previous study, the empathy was an important influential factor towards customer satisfaction. Therefore, the hypothesis was formed based on the discussion above as follow:

H4: Empathy of National Courier Services parcel delivery positively affects customer satisfaction.

Price

Among most important factors for customer satisfaction is price, and there are many researches that have studied the relationship between price and customer satisfaction. Price is the main element consumer consider when evaluate the value of a goods and service. Customers tend to make comparison between prices with the value or superiority of good and service they received. If the perceived value or customer satisfaction towards a products were higher than its expense, customers were willing to buy the products (Nasirabadi and Bokaei, 2013; Yoon and Kim, 2000).

According to Mlekwa (2014); Shahzad and Saima (2012), price is one of the component affecting customer satisfaction. The increase or decrease of price give a huge impact towards customer satisfaction and brand switching (Saleh, Althonayan, Alhabib, Alrasheedi, \& Alqahtani, 2015; Faryabi, Sadeghzadeh, \& Saed, 2012). It also found to be affecting the perceptions and satisfactions of the customers thus on their purchase intention. Customers were willing to purchase more when the price were under their satisfaction area (Hosseini, Mosayebi, \& Khorram, 2013; Shirai, 2009). Wulan and Husaeni (2015); Schiffman and Kanuk (2004) meanwhile, stated that price of a product either low, high or affordable have a robust impact on the satisfaction and reason to purchase.

Uddin and Akhter (2012) founded the level of price, money value and promotion would contribute to both customer satisfaction and dissatisfaction. However, price fairness, processibility and perceptibility of price would due to customer's dissatisfaction. The research of Nazari, Hosseini and Kalejahi (2014), in their study of the banking industry indicated price perception would affect the customer satisfaction, customer switching power and word of mouth. Therefore, there was an important relationship between price, service quality and goods towards customer satisfaction (Hasniaty, 2015). As summary of the result of previous studies, price was an important influential factors on the customer satisfaction. Hence, the hypothesis was formed based on the discussion above as follow:

H5: Price of National Courier Services parcel positively affects customer satisfaction. 


\section{RESEARCH DESIGN}

\section{Population and Sampling Methods}

The respondent of this research was focus on consumers which has experienced using parcel service delivery who were currently and permanently reside in Kota Samarahan, Sarawak. The target population was suitable for aims of the study as a large number of resident of Kota Samarahan were students of various higher learning institutions, whose age range is demographically similar to key age demographic for online shopper (Smith, 2015). In addition, as it is located far from Peninsular Malaysia, the residents of Kota Samarahan, in particular students, were more likely to shop online.

In this study, non-probability methods which was snowball sampling is used. Crossman (2018) mentioned snowball sampling was a very good technique for conducting exploratory research with a specific and relatively small population that was hard to identify or locate. The information was obtained from a few individuals in a group and they were asked to identify other people in the group to become a part of the sample. From 87,923 people in Kota Samarahan, a total number of 400 questionnaires were distribute to the target respondents.

\section{Research Instrument}

This research has used self-administered questionnaire and the questionnaire has distributed personally to the respondents. The questionnaire consists of three sections. In Section A, respondent's demographic profile and three questions regarding their previous experience on courier service were asked. The three questions were adapted from Mlekwa (2014), namely, "Have you experience using any courier/shipping service before?", "Which is the courier service or shipping service do you use the most?" and "Have you experience using National Courier Services service before?"

Section B was about the influence of independent variables - reliability, responsiveness, assurance, empathy and price - towards the customer's level of satisfaction. Meanwhile, respondents were asked about their satisfaction towards parcel delivery service of National Courier Services in Section C. All questions in both Section B and Section C were answered in 6-point Likert Scale as it gives higher reliability value and discrimination compared to 5-point Likert scale (Chomeya, 2010). The measurement items and its sources for questions in Section B and Section C are shown in Table 1.

Table 1: Measurement item for Section B and C

\begin{tabular}{l|l}
\hline \multicolumn{1}{c}{ List of Questions } & \multicolumn{1}{c}{ Source } \\
\hline Reliability: & Adopted from Goh, Kow, \\
National Courier Services postman are dependable. & Lee, Loh and Sam (2013) \\
If National Courier Services promises to do something by a & \\
certain time, they do so. & \\
National Courier Services postman delivers my parcel on time. \\
National Courier Services make sure my parcel delivery tracking \\
status is updated.
\end{tabular}


INTERNATIONAL JOURNAL OF ACADEMIC RESEARCH IN BUSINESS AND SOCIAL SCIENCES

Vol. 8, No. 12, Dec, 2018, E-ISSN: 2222-6990 (C) 2018 HRMARS

National Courier Services inform or call me when they reach my house to deliver the parcels.

Responsiveness:

National Courier Services provide prompt service to customers. Postman of National Courier Services ready to help customers. Postman able to reply to any query or question from customers.

National Courier Services care about their customers.

Postman of National Courier Services always delivers the right and actual parcel to customers.

Assurance:

When customers have problems, National Courier Services is kind and supportive.

Customers feel safe in delivers their parcel with National Postage (National Courier Services).

The postman of National Courier Services assures customers. Postman of National Courier Services is polite.

Postman of National Courier Services has the willingness to install confidence in customers.

\section{Empathy:}

Customer service of National Courier Services is caring in serving their customers.

National Courier Services give individual attention to customers.

Postman of National Courier Services is aware of the customer's needs.

The postman of National Courier Services are easy to communicate with.

Customer service of National Courier Services are always available for customers.

\section{Price:}

The price of National Courier Services parcel is reasonable.

The price of National Courier Services parcel is fair for service. The price of National Courier Services parcel is within my expectation.

National Courier Services provides the price that is competitive. The price of National Courier Services does not affect my parcel delivery process.

\section{Customer Satisfaction:}

I am satisfied with the safety and condition of my parcel. I am satisfied with the postman of National Courier Services attitude.
Adopted from Goh et al.

(2013)

Adopted from Goh et al. (2013)

Adopted from Goh et al. (2013)

Adopted from Mlekwa (2014)

Adopted from Goh, et al. (2013) 
I am satisfied with the accuracy of information provided about my parcel.

I am satisfied with the service provided by customer service of National Postage (National Courier Services).

Overall, I am satisfied with National Courier Services courier service.

\section{RESULTS AND DISCUSSION \\ Demographic}

Based on the data collected, from 400 respondents that participated in the survey, $70 \%$, or 280 respondents, were female and 30\% (120 respondents) were male. $61.5 \%$ or 246 respondents are from the age range between 20 to 29 years old. This was followed by the age group of 30 to 39 years old (21.8\%), 40-49 years old (8.8\%), below 20 years old $(6.0 \%)$, and 50 years old and above $(2.0 \%)$. Students made the majority of respondents with $51.3 \%$ or 201 respondents, followed by public servant $(20.0 \%)$, self-employed $(11.3 \%)$, employees of private companies $(12.3 \%)$, retiree $(3.0 \%)$ and unemployed (2.3\%).

The following demographic factor was monthly income of respondents. The result has shown the highest percentage went to those without any income, which was amounted to 52.5\% (210 respondents). As majority of the respondents were students, it is understandable that group without any income would also be the highest in term of income. The second highest percentage which amounted to $17.5 \%$ of the respondents are having monthly income between RM2001 to RM3000. This was followed by respondents with monthly income between RM1001-RM2000 (14.8\%), below RM1000 (8.3\%) and 3001 and above (7.0\%).

\section{Reliability Test and Normality Test}

Based on reliability test, all variables used in this study were internally consistent and reliable as Cronbach's Alpha for all variables were higher than 0.70 (Wulan \& Husaeni, 2015, Minh, Ha, Anh, \& Matsui, 2015). The alpha value of reliability was at 0.966, responsiveness (0.954), assurance (0.964), empathy (0.967), price $(0.750)$ and customer satisfaction (0.969). Thus, all the variables were at the acceptable range in this study.

The normality test was then used to determine whether sample data has been drawn from a normally population. An acceptable range of skewness and kurtosis was greater than +1.96 or lesser than -1.96 was significant at $P<0.05$. The skewness showed the value of 0.76 and kurtosis value of -1.11 which both was in the range of +1.96 and -1.96 . This means the data were normally distributed (Ghasemi \& Zahediasl, 2012).

\section{Pearson Correlation Analysis}

In this research, Pearson correlation coefficient is used to measure the correlation between independent variables, which are reliability, responsiveness, assurance, empathy and price, with customer satisfaction as dependent variable. Based on Pearson Correlation Analysis, the result 
INTERNATIONAL JOURNAL OF ACADEMIC RESEARCH IN BUSINESS AND SOCIAL SCIENCES

Vol. 8, No. 12, Dec, 2018, E-ISSN: 2222-6990 @ 2018 HRMARS

showed all independent variables were found to be significantly and positively correlated with dependent variable, with $P=0.01$. Assurance was found to have the highest correlation with customer satisfaction at 0.725 , followed by reliability $(0.717)$, responsiveness $(0.670)$, empathy (0.638) and price (0.556). Except for price, it is therefore all independent variables are found to have a strong relationship with customer satisfaction., whereas, there was a moderate relationship between price and customer satisfaction.

\section{Multiple Linear Regression Analysis}

In this research, multiple linear regression was used to explain the relationship between one continuous dependent variable, which is customer satisfaction with all five independent variables. Table 2 showed the model summary of multiple regression analysis for this research. As shown in in Table 2 below, the coefficient of determination, $R^{2}$ was found to be at 0.663 . It is therefore can be interpreted as $66.3 \%$ of variation of customer satisfaction was described by independent variables, namely reliability, responsiveness, assurance, empathy and price. Even after taking into account the number of predictor variables in the model, the adjusted value of coefficient of determination was found to be at 0.659 , giving an indication that $65.9 \%$ of the variation of customer satisfaction was described by independent variables based on the adjusted number of independent variables used.

Table 2: Model Summary

\begin{tabular}{cccc}
\hline $\boldsymbol{R}$ & $\boldsymbol{R}$ Square & Adjusted $\boldsymbol{R}$ Square & Standard Error of the Estimate \\
\hline $0.814^{a}$ & 0.663 & 0.659 & 0.46237 \\
\hline
\end{tabular}

Table 3: Coefficients

\begin{tabular}{|c|c|c|c|c|c|}
\hline \multirow[t]{2}{*}{ Model } & \multicolumn{2}{|c|}{$\begin{array}{c}\text { Unstandardized } \\
\text { Coefficients }\end{array}$} & \multirow{2}{*}{$\begin{array}{c}\text { Standardize } \\
d \\
\text { Coefficients } \\
\text { Beta }\end{array}$} & \multirow[t]{2}{*}{ t-value } & \multirow[t]{2}{*}{$\begin{array}{c}\text { Significant } \\
\text { level }\end{array}$} \\
\hline & B & $\begin{array}{l}\text { Standar } \\
\text { d Error }\end{array}$ & & & \\
\hline (Constant) & 0.275 & 0.097 & & 2.846 & 0.005 \\
\hline Reliability & 0.192 & 0.040 & 0.230 & 4.852 & 0.000 \\
\hline $\begin{array}{c}\text { Responsivenes } \\
s\end{array}$ & 0.136 & 0.036 & 0.169 & 3.798 & 0.000 \\
\hline Assurance & 0.248 & 0.036 & 0.311 & 6.930 & 0.000 \\
\hline Empathy & 0.083 & 0.034 & 0.105 & 2.434 & 0.015 \\
\hline Price & 0.175 & 0.037 & 0.166 & 4.713 & 0.000 \\
\hline
\end{tabular}

Based on the beta $(\beta)$ in standardized coefficients in Table 3 above, assurance was the highest with the value of 0.311 . This would mean that among all five variables, assurance is the most significant dimension that would affect customer satisfaction of parcel delivery service by National Courier Services. This is followed by reliability at beta value of 0.230 , responsiveness $(0.169)$, price $(0.166)$ and empathy (0.105). Based on these values and the value of constant in Table 3, the multiple linear regression equation can be formed as below. 
INTERNATIONAL JOURNAL OF ACADEMIC RESEARCH IN BUSINESS AND SOCIAL SCIENCES

Vol. 8, No. 12, Dec, 2018, E-ISSN: 2222-6990 @ 2018 HRMARS

Customer Satisfaction $=0.275+0.230$ Reliability +0.169 Responsiveness + 0.311 Assurance + 0.105 Empathy +0.166 Price

Based on the equation above, for every unit of increase in assurance, customer satisfaction towards parcel delivery service of National Courier Services would increase by 0.311 , with other factors remain constant. The same interpretation of beta value towards the increment of customer satisfaction can be applied for all variables. Based on Table 3 above, all hypotheses are accepted, as all variables show significant value lower than 0.05 .

\section{Discussion}

Among all five variables studied in this research, assurance is found to be the most significant determinants of customer satisfaction towards parcel delivery service of National Courier Service. Finding of this research is also found to be consistent with the finding of previous researches (Goh, Kow, Lee, Loh, \& Sam, 2013; Anjalika \& Priyanath, 2018; Adil, 2013). With element of assurance given by National Courier Services when dealing with customers, customers would feel safe and have confidence that the company is able to manage and deliver their parcel to its intended destination.

In addition, accurate recode and confidentiality of tracking status are among indications that would make parcel delivery service reliable. Based on the finding of this research, reliability is found to be the next most significant predictor of customer satisfaction towards parcel delivery services. The result is also consistent with studies done by Horsu and Yeboah (2015), Markovic and Jankovic (2013), and Mahfooz (2014).

Towards increasing their customer satisfaction, the third significant dimension of service quality that National Courier Services should put priority on is responsiveness. Through responsiveness, customers are able to feel themselves as an important customer to the company. Employees must be able to respond to customers' inquiries and problems as quick as they can. In addition, the company need to show special attention and if possible, personalized customer care towards their customer in order to develop loyalty. The finding of this research is also consistent with Nautiyal (2014), Rosha and Kaur (2018), and Chong, Lim, Ng and Wong (2016).

In addition, National Courier Services could also enhance its customer satisfaction by providing an affordable and fair price for its service, as the price is found to be positively linked with customer satisfaction. This result is supported by result from Mai and Ngo (2016) and Almohaimmeed (2017). The least significant dimension that affect National Courier Services' customer satisfaction is empathy. Although it is found to be the least significant dimension, there is a positive relationship between empathy and customer satisfaction, suggesting that the element of empathy cannot be ignored by the company in increasing their customer satisfaction. This is consistent with the finding of Khamis (2013), Alshatnawi and Amlus (2016), and Karim and Chowdhury (2014). 


\section{CONCLUSION}

Through this research, researcher examine the relationship between five independent variables, namely reliability, responsiveness, assurance, empathy and price, with customer satisfaction of National Courier Services. Based on the findings, it is found that all dimensions are influencing customer satisfaction, with the most significant dimension is assurance, followed by reliability, responsiveness, price and empathy. Based on these findings, it is hoped that National Courier Services is able to be more efficient and effective in their operation, thus improving their service to customer and increasing customer satisfaction.

For theoretical perspective, there were a lot of researches had adopted SERVQUAL model's five dimensions. However, in this research, researchers had adapted the model from Parasuraman, et. al. (1985) by only adapting four dimension which were reliability, responsiveness, assurance and empathy, and added one more additional attribute, which is price. The tangibles dimension was not used as there was no significant appearance of physical facilities or equipment used by a customer throughout the process of parcel delivery. In this sense, this research has contributed to a theoretical contribution as there was limited number of researches done using the four service quality dimensions and price. The same can also be said towards research on parcel delivery services in Malaysia, especially after the booming of online business in the country. Hence, the findings of this research could be beneficial to future researchers interested to study on this industry.

This research was done by focusing on the perception of respondents. A total of 400 respondents from Kota Samarahan area was involved in this research. However, it is recommended in future research to include customer expectation as part of measurement. The gap between the expectation and perception should be investigate in order to allow the researcher to better evaluate customer satisfaction with National Courier Services. In addition, future researchers are encouraged to expand the sample size of the respondent as larger sample size would result in higher tendency of a result to be more accurate.

\section{Acknowledgement}

The authors acknowledge the financial support from Universiti Malaysia Sarawak (UNIMAS) and Research Acculturation Grant Scheme No. RAGS/SS05(2)/1185/2014(08) and supported by Ministry of Higher Education, Malaysia. All remaining flaws are the responsibilities of the authors.

\section{REFERENCES}

Abili, K., Narenji Thani, F., Mokhtarian, F., \& Mehdi Rashidi, M. (2011). Assessing Quality Gap of University Services. Asian Journal on quality, 12(2), 167-175.

Adil, M. (2013). The relationship between service quality and Customer Satisfaction in India's Rural Banking Sector: An Item Analysis and Factor-specific Approach. The Lahore Journal of Business, 1(2), 43-63.

Aljasser, I. A., \& Sasidhar, B. (2016). Bank Customers' Perception of Service Quality and Customer Satisfaction in Saudi Arabia. European Journal of Business and Social Sciences, 4(11), 130 141. 
INTERNATIONAL JOURNAL OF ACADEMIC RESEARCH IN BUSINESS AND SOCIAL SCIENCES

Vol. 8, No. 12, Dec, 2018, E-ISSN: 2222-6990 @ 2018 HRMARS

Almohaimmeed, B. M. A. (2017). Restaurant quality and customer satisfaction. International Review of Management and Marketing, 7(3), 42-49.

Anggorowati, E. A. (2015). Analysis of service quality on building loyalty by using structural equation modelling method. Journal of the Civil Engineering Forum, 1, 57-62.

Anjalika, W. P. W., \& Priyanath, H. M. S. (2018). Effect of Service Quality on Customer Satisfaction: An empirical study of customers who have bank accounts in both public and private banks in Sri Lanka. International Journal of Marketing and Technology, 8(1), 11-36.

Arokiasamy, A. R. A., \& Abdullah, A. G. (2013). Service quality and customer satisfaction in the cellular telecommunication service telecommunication service provider in Malaysia. Journal of Arts, Science and Commerce, 4, 1-9.

Baruah, D., Nath, T. \& Bora, D. (2015). Impact of service quality dimensions on customer satisfaction in telecom sector. International Journal of Engineering Trends and Technology, 27, 111-117.

Bharwana, T. K., Bashir, M., \& Mohsin, M. (2013). Impact of service quality on customers' satisfaction: a study from service sector especially private colleges of Faisalabad, Punjab, Pakistan. International Journal of Scientific and Research Publications, 3, 1-7.

Bradić, M., Kosar, L., \& Kalenjuk, B. (2013). Business guests satisfaction in the hotel industry: A case study of North American hotel chains. Turizam, 17(2), 60-70.

Chomeya, R. (2010). Quality of psychology test between Likert scale 5 and 6 points. Journal of Social Sciences, 6(3), 399-403.

Chong, Y. T., Lim, E. M., Ng, C. Y., \& Wong, C. S. (2016). Factors that affecting customer satisfaction among local tourists towards budget hotels in Malaysia (Thesis). Retrieved from http://eprints.utar.edu.my/2017/1/MK-2016-1201475.pdf

Choy, J., Ma, N. L., \& Koo, P. S. (2013). Performance measurement design for a parcel delivery company. Proceedings of the World Congress on Engineering, 3, Research Collection School of Information systems.

Cook, S. (2000). Customer Care. How to Create an Effective Customer Focus? (3rd ed.). London, Kogan Page.

Cronin, J., \& Taylor, S. A. (1992). Measuring Service Quality: A Reexamination and Extension. Journal of Marketing, 56, 55-67.

Datta, K. S., \& Vardhan, J. (2017). A SERVQUAL-Based Framework for Assessing Quality of International Branch Campuses in UAE: A Management Students' Perspective. SAGE Open, 7(1), 2158244016676294.

Das, A., Kumar, V., \& Saha, G. C. (2010). Retail service quality in context of CIS countries. International Journal of Quality \& Reliability Management, 27(6), $\quad$ 658-683.

Faryabi, M., Sadeghzadeh, K., \& Saed, M. (2012). The effect of price discounts and store image on consumer's purchase intention in online shopping context case study: Nokia and HTC. Journal of Business Studies Quarterly, 4(1), 197-205.

Felix, R. (2017). Service quality and customer satisfaction in selected banks in Rwanda. Journal of Business \& Financial Affairs, 6(1), 246-256.

Firdous, S. (2017). Impact of internet banking service quality on customer satisfaction. Journal of Internet Banking and Commerce, 22(1), 1-17. 
INTERNATIONAL JOURNAL OF ACADEMIC RESEARCH IN BUSINESS AND SOCIAL SCIENCES Vol. 8, No. 12, Dec, 2018, E-ISSN: 2222-6990 @ 2018 HRMARS

George, A., \& Kumar, G. S. G. (2014). Impact of service quality dimensions in internet banking on customer satisfaction. Decision, 14(1), 73-85.

Ghalib, S. (2014). The Impact of Service Quality Delivery on Customer Satisfaction in the Banking Sector in Riyadh, Saudi Arabia. International Journal of Business Administration, 5(4), 77-84.

Ghasemi, A., \& Zahediasl, S. (2012). Normality tests for statistical analysis: a guide for nonstatisticians. International journal of endocrinology and metabolism, 10(2), 486-9.

Goh, M. L., Yeo, S. F., Lim, K. B., \& Tan, S. H. (2016). Understanding customer satisfaction of internet banking: a case study in Malacca. Procedia Economics and Finance. 37(16), 80-85.

Goh, P. S., Kow, W. S., Lee, Y. C., Loh, W. N., \& Sam, K. H. (2013). The relationship between service quality and customer satisfaction: an empirical study in banking industry (Thesis). Retrieved from http://eprints.utar.edu.my/1040/1/BF-2013-1005121-1.pdf

Gulc, A. (2017). Models and methods of measuring the quality of logistics service. Procedia Engineering, 182(17), 255-264.

Hasniaty (2015). Customer perception on products, pricing, service quality, towards customer's quality relationships and loyalty of domestic airlines, Indonesia. International Journal of Scientific and Technology Research. 4(12), 181-188.

Hennayake, H. M. G. Y. J. (2017). Impact of service quality on customer satisfaction of public sector commercial banks: a study on rural economic context. Journal of Scientific and Research Publications, 7(2), 156-160.

Hom, W. (2000). An Overview of Customer Satisfaction Models, Policy, Planning \& External Affairs Division. California Community Colleges, California.

Horsu, E. N., \& Yeboah, S. T. (2015). Influence of service quality on customer satisfaction: A study of minicab taxi services in Cape Coast, Ghana. International Journal of Economics, Commerce and Management, 3(5), 1451-1464.

Hosseini, S. H. K., Mosayebi, A. \& Khorram, J. (2013). Investigating the effects of emotional and social stimulants of stores atmosphere and prices on the customers' satisfaction and loyalty. Management Science Letters. 3(13), 1521-1528.

Jamal, A., \& Anastasiadou, K. (2009). Investigating the effects of service quality dimensions and expertise on loyalty. European Journal of Marketing, $\quad 43(3 / 4), 398-420$.

Johnston, R. (1995). The determinants of service quality: Satisfiers and dissatisfiers. International Journal of Service Industry Management, 6(5), 53-71.

Khamis, A. R. (2013). An examination of the relationship between service quality and customer satisfaction on mobile broadband provider: the case of Zantel, Zanzibar (Master's Thesis).

Retrieved from

http://scholar.mzumbe.ac.tz/bitstream/handle/11192/578/MBA\%20DissertationAmne\%20Rashid\%20Khamis-.2013.pdf?sequence=1

Kim, H. (2015). E-commerce set for growth. The Star Online. Retrieved from https://www.thestar.com.my/metro/smebiz/news/2015/12/28/ecommerce-set-for-growth/

Kotler, P. (2000). Marketing Management, the Millennium Edition. New Jersey, Prentice Hall.

Ladhari, R., Ladhari, I., \& Morales, M. (2011). Bank service quality: comparing Canadian and Tunisian customer perceptions. International Journal of Bank Marketing, 29(3), 224-246. 
INTERNATIONAL JOURNAL OF ACADEMIC RESEARCH IN BUSINESS AND SOCIAL SCIENCES

Vol. 8, No. 12, Dec, 2018, E-ISSN: 2222-6990 @ 2018 HRMARS

Large, R. O., \& König, T. (2009). A gap model of purchasing's internal service quality: Concept, case study and internal survey. Journal of purchasing and supply management, 15(1), 24-32.

Lee, Y.J. (2000). A theoretical examination of customer satisfaction research: findings and outlook. Journal of Consumer Studies, 11(2), 139-166.

Liu, H. Y. (2003). A customer relationship management approach to a study of e-commerce strategy in Taiwan's banking industry. Chiao Da Management Review, 23(2), 1-36.

$\mathrm{Ma}$, Z. (2012). Assessing serviceability and reliability to affect customer satisfaction of internet banking. Journal of Software, 7(7), 1601-1607.

Mai, N. K., \& Ngo, Q. D. (2016). The factors affecting customer satisfaction and customer loyalty A study of Local Taxi Companies in Ho Chi Minh City, Vietnam. International Journal of Innovation, Management and Technology. 7(5), 228.

Madu, C. N., \& Madu, A. A. (2002). Dimensions of e-quality. International Journal of Quality \& Reliability Management, 19(3), 246-58.

Mahfooz, Y. (2014). Relationship between service quality and customer satisfaction in hypermarkets of Saudi Arabia. International Journal of Marketing Studies, 6(4), 10.

Markovic, S., \& Jankovic, S. R. (2013). Exploring the relationship between service quality and customer satisfaction in Croatian hotel industry. Tourism and Hospitality Management, 19(2), 149-164.

Mensah, F. M. (2014). How parcel (package) delivery firms can minimize the high returns (sendsagains) in the supply chain industry (Master's Thesis). Retrieved from https://gupea.ub.gu.se/bitstream/2077/37777/1/gupea 207737777 1.pdf

Millas, A. (2013). The link between services quality and customer satisfaction in the retail banking in Tanzania, case study of CRDB bank (Master's Thesis). Retrieved from http://repository.out.ac.tz/1052/1/millas final.pdf

Minh, N. H., Ha, N. H., Anh, P. C., \& Matsui, Y. (2015). Service quality and customer satisfaction: a case study of hotel industry in Vietnam. Asian Social Science. 11(10), 73-85.

Mlekwa, M. D. (2014). The effect of price fairness and customer service on customer satisfaction the case of mobile phone users of Tanga City (Master's Thesis). Retrieved from http://scholar.mzumbe.ac.tz/bitstream/handle/11192/1157/MSc_MBA-

CM_Moses\%20Denis\%20Mlekwa_2014.pdf?sequence=1

Mokhtar, M. (2013). Reject arrogance and shoddy service. Retrieved from http://www.freemalaysiatoday.com/category/opinion/2013/06/25/reject-arrogance-andshoddy-service/

Morganti, E., Seidel, S., Blanquart, C., Dablanc, L., \& Lenz, B. (2014). The impact of e-commerce on final deliveries: alternative parcel delivery services in France and Germany. Transportation Research Procedia, 4(14), 178-190.

Munusamy, J., Chelliah, S., \& Mun, H. W. (2010). Service quality delivery and its impact on customer satisfaction in the banking sector in Malaysia. International Journal of Innovation, Management and Technology, 1(4), 398.

Nasirabadi, E. Z. \& Bokaei, M. N. (2013). A study on relationship of brand characteristics and customer satisfaction with brand loyalty. Management Science Letters, 3(13), 1907-1914.

Nautiyal, G. (2014). Impact of service quality on customer satisfaction in the retail banking sector. Global Journal of Commerce and Management Perspective, 3(3), 77-80. 
INTERNATIONAL JOURNAL OF ACADEMIC RESEARCH IN BUSINESS AND SOCIAL SCIENCES

Vol. 8, No. 12, Dec, 2018, E-ISSN: 2222-6990 @ 2018 HRMARS

Nazari, M., Hosseini, M.A.S., \& Kalejahi, S.V.T. (2014). Impact of price fairness on price satisfaction, customer satisfaction and customer loyalty in Iran Telecommunication. Research in Marketing, 3(1), 131-144.

Nupur, J. M. (2010). E-Banking and Customers' Satisfaction in Bangladesh: An Analysis. International Review of Business Research Paper, 6(4), 145-156.

Oliver, R. L. (1997). Satisfaction: A behavioral perspective on the consumer. New York. Irwin/McGrawHill.

Oliver, R. L. (1980). A cognitive model of the antecedents and consequences of satisfaction decisions. Journal of marketing research, 460-469.

Omar, H. F. H., Saadan, K. B., \& Seman, K. B. (2015). Determining the influence of the reliability of service quality on customer satisfaction: the case of Libyan e-commerce customers. International Journal of Learning \& Development, 5(1), 86-89.

Omar, M. S., Ariffin, H. F., \& Ahmad, R. (2016). Service quality, customers' satisfaction and the moderating effects of gender: a study of Arabic Restaurants. Social and Behavioral Sciences Procedia, 224(16), 384-392.

Parasuraman, A., Zeithaml, V. A., \& Berry, L. L. (1985). A conceptual model of service quality and its implications for future research. the Journal of Marketing, 41-50.

Parasuraman, A., Zeithaml, V. A., \& Berry, L. L. (1988). SERVQUAL: a multiple-item scale for measuring consumer perceptions of service quality. Journal of Retailing, 64(1), 12-40.

Phan, C. A. (2015). Impact of service quality on customer satisfaction of automated teller machine service: Case study of a private commercial joint stock bank in Vietnam. Business: Theory and Practice, 16, 280-289.

Phiri, M. A. \& Mcwabe, T. (2013). Customers' expectations and perceptions of service quality: the case of pick n pay supermarket stores in Pietermaritzburg area, South Africa. International Journal of Research in Social Sciences, 3(1), 96-104.

Qadri, U. A. (2015). Measuring service quality expectation and perception using SERVQUAL: A gap analysis. Business and Economics Journal, 6(3), 1.

Razak, I., Nirwanto, N., \& Triatmanto, B. (2016). The impact of product quality and price on customer satisfaction with the mediator of customer value. Journal of Marketing and Consumer Research. 30, 59-68.

Rosha, R., \& Kaur, D. N. (2018). Relationship between RATER Service Quality Dimensions and Customer Satisfaction-Study on Travel Agents in Punjab. Researchers World, 9(1), 160.

Roslan, N. A. A., Wahab, E. \& Abdullah, N. H. (2015). Service quality: A case study of logistics sector in Iskandar Malaysia using SERVQUAL Model. Social and Behavioral Sciences Procedia, 172(15), 457-462.

Saleh, M. A. H., Althonayan, A., Alhabib, A., Alrasheedi, E., \& Alqahtani, G. (2015). Customer satisfaction and brand switching intention: a study of mobile service in Saudi Arabia. Expert Journal of Marketing, 3(2), 62-72.

Schiffman, LG. \& Kanuk, LL. (2004). Consumer behavior (8th ed.). Prentice Hall.

Shahzad Khan, S. A. (2012). Determinants of customer satisfaction in telecom industry: a study of telecom industry Peshawar KPK Pakistan. Journal of Basic and Applied Scientific Research, 2(12), 12833-12840. 
INTERNATIONAL JOURNAL OF ACADEMIC RESEARCH IN BUSINESS AND SOCIAL SCIENCES

Vol. 8, No. 12, Dec, 2018, E-ISSN: 2222-6990 @ 2018 HRMARS

Shanka, M. S. (2012). Bank service quality, customer satisfaction and loyalty in Ethiopian banking sector. Journal of Business Administration and Management Sciences Research, 1(1), 001-009.

Shirai, M. (2009). Investigation of emotional responses to an unexpected price. Australasian Marketing Journal (AMJ), 17(1), 2-8.

Subashini, R. (2016). A review of service quality and customer satisfaction in banking services: Global scenario. The Journal of Internet Banking and Commerce, 21(5). Retrieved from http://www.icommercecentral.com/open-access/a-review-of-service-quality-and-customersatisfaction-in-banking-services-global-scenario.pdf

Siami, S. \& Gorji, M. (2012). The measurement of service quality by using SERVQUAL and quality gap model. Indian Journal of Science and Technology, 5(1).

Smith, C. (2015). The surprising facts about who shops online and on mobile. Retrieved from https://www.businessinsider.com/the-surprising-demographics-of-who-shops-online-andon-mobile-2014-6/?IR=T

Stefano, N. M., Casarotto, F. N., Barichello, R., \& Sohn, A. P. (2015). A Fuzzy SERVQUAL based method for evaluated of service quality in the hotel industry. Procedia CIRP, 30(15), 433-438.

Su, L., Swanson, S. R., \& Chen, X. (2016). The effects of perceived service quality on repurchase intentions and subjective well-being of Chinese tourists: the mediating role of relationship quality. Tourism Management, 52(16), 82-95.

Szymanski, D.M., \& Henard, D.H. (2001). Customer satisfaction: a meth- analysis of the empirical evidence. Journal of Academy of Marketing Science, 29(1), 16-35.

Temba, M. L. (2013). The assessment of service quality and customer satisfaction using SERVQUAL Model: A case study of Tanzania Telecommunications Company Limited (Master's Thesis). Retrieved from http://repository.out.ac.tz/937/1/marry_temba.pdf

Uddin, M. B., \& Akhter, B. (2012). Customer satisfaction in mobile phone services in Bangladesh: A Survey Research. Management and Marketing, 10(1), 21-34.

Wirtz, J., Mattila, A. S., \& Tan, R. L. (2000). The moderating role of target-arousal on the impact of effect on satisfaction-an examination in the context of service experiences. Journal of Retailing, 76(3), 347-365.

Wulan, E. R., \& Husaeni, U. A. (2015). Analysis of the variables that affect bookstore customer satisfaction. International Journal of Nusantara Islam, 3(2), 27-36.

$\mathrm{Xu}$, J., Ling, J., Li, Y. (2013). Service requirement for terminal delivery: An empirical study from the perspective of online shoppers. Journal of Industrial Engineering and Management, 6(4), 1223-1237.

Yavas, U., Bilgin, Z., \& Shemwel, D. J., (1997). Service quality in the banking sector in an emerging economy: a consumer survey. International Journal of Bank Marketing, 15(6), 217-223.

Yeo, G. T., Thai, V. V., \& Roh, S. Y. (2015). An analysis of port service quality and customer satisfaction: The Case of Korean Container Ports. The Asian Journal of Shipping and Logistics, 31(4), 437447.

Yoon, S. J., \& Kim, J. H. (2000). An empirical validation of a loyalty model based on expectation disconfirmation. Journal of Consumer Marketing, 17(2), 120-136.

Yousapronpaiboon, K. (2014). SERVQUAL: Measuring higher education service quality in Thailand. Social and Behavioral Science Procedia, 116(14), 1088-1095. 
INTERNATIONAL JOURNAL OF ACADEMIC RESEARCH IN BUSINESS AND SOCIAL SCIENCES

Vol. 8, No. 12, Dec, 2018, E-ISSN: 2222-6990 @ 2018 HRMARS

Yuen, E. F. T., \& Chan, S. S. L. (2010). The effect of retail service quality and product quality on customer loyalty. Database Marketing \& Customer Strategy Management, 17(3/4), 222240. 